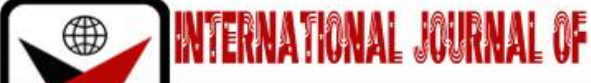

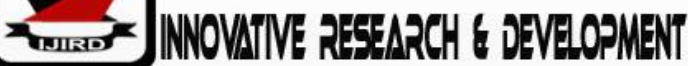

ISSN 2278-0211 (Online)

\section{Inflation Rate and Economic Growth in Rwanda}

\author{
Ntagara Jane \\ Student, Department of Business Administration, School of Business, \\ Jomo Kenyatta University of Agriculture and Technology, Kenya \\ Dr. Patrick Mulyungi \\ Lecturer, Jomo Kenyatta University of Agriculture and Technology, Kenya
}

\begin{abstract}
:
The objective of macroeconomic policies is to achieve a high economic growth rate while maintaining a low inflation rate, it is also believed that a high inflation has an adverse effect on economic growth. But how low should the inflation rate be not to impact negatively on economic growth? The study assumed a nonlinear relationship between inflation and economic growth and attempts to identify the existence of threshold effects between these variables in the case of Rwanda using time series the period 2003-2019. Data was analyzed by means of a quadratic regression model and ordinary least square technique. The results showed that at low levels, inflation does not hurt economic growth, while at higher levels, inflation reduces economic growth. The estimated inflation threshold level is $14.97 \%$. Since the findings of this study have unveiled the estimated threshold inflation rate consistent with economic growth in Rwanda, they would provide some useful guidance to economic decision makers in designing a more appropriate macroeconomic policy framework.
\end{abstract}

Keywords: Influence of macroeconomic variables, high economic growth rate, and low inflation

\section{Introduction}

Inflation can be defined as an expansion in the quantity of money in circulation (Haberler, 2009) or defined as persistent decreases of the money value (Makinen, 2010). Consequently, inflation lowers the purchasing power of the people as they need more money to purchase one unit of good or service. Hence, people spend huge amount of money for consumption. Saving and investment decline as result: resulting in higher unemployment and lower economic growth. However, to overcome the hindrance of inflation in economy, most of central banks in developed and developing countries have the core objective to keep inflation at minimum rate for achieving and maintaining high economic growth. In the same way, National Bank of Rwanda (N.B.R) aims to keep price stability towards sustainable economic development. Considering this, to achieve price stability (low inflation rate) N.B.R monetary policy works under flexible monetary targeting with two tools, i.e., reserve money used to increase or decrease liquidity in the banking system and Broad money (M3) used to manage the money supply with targeted inflation and economic growth.

Inflation makes investment doubtful for both domestic and foreign investors. Also, it destroys the terms of trade in the country by increasing the price of domestic goods more than the regional and the world market price. As a result, trade becomes non-competitive to the global market (Ananias and Valence, 2012). Accordingly, the non-competitive of trade leads to the deficit in the current account.

Rwanda's annual inflation climbed to 11.8 percent in November 2019 from 7.2 percent in the previous month. This is the highest inflation rate since April 2017. Prices rose mostly for food \& non-alcoholic beverages (23.8 percent vs 14.2 percent in October), namely vegetables (36.1 percent vs 18 percent); bread \& cereals (22.9 percent vs 18.2 percent) and meat (19.2 percent vs 18.1 percent), in part reflecting the impact of frequent rains over the past few months. Additional upward pressure came from alcoholic beverages \& tobacco (19.1 percent vs 7 percent); housing \& utilities (1.4 percent vs 0.3 percent) and miscellaneous goods \& services ( 3.6 percent vs 3.4 percent). On a monthly basis, consumer prices inched up 3.8 percent, after increasing 1.4 percent in the previous month. Inflation Rate in Rwanda averaged 5.82 percent from 1997 until 2019, reaching an all-time high of 28.10 percent in February of 1998 and a record low of -15.80 percent in February of 1999.

\subsection{Statement of the Problem}

After 1994, the economic growth of Rwanda has growth significant a lot was done in macroeconomics variables, by increasing economic output, decrease unemployment rate, decrease an inflation rate, increase savings and investment. A study done by African Development Bank group (2010) states that in the pursuit of the policy goal of making Rwanda a preferred foreign investment destination, and to attract particular investors to establish in Africa, government of Rwanda has legislated exchange rate inventively. Available data suggests that the impact of these exemptions and incentives in terms of exchange rate foregone is significant. The economic growth In Rwanda has been increasing year after another as 
evidenced by the different annual Government reports. However, this has not been fully reflected in reality from those reports, what contributes to this economic growth.

Moreover, the management of the National Bank of Rwanda has been envisaging a shift from monetary targeting to inflation targeting regime to conduct monetary policy. In case the latter regime is adopted, a single level value or a range of inflation level values to be targeted must be determined; in this context, the present research may be helpful in the determination of such targets. The last motivation for this research was that, the availability of data spanning the period 2010-2019, which is more than decades for the case of Rwanda, allows meaningful time series investigation and valid statistical inference.

Most of the studies conducted on the inflation threshold effects on economic growth employed cross-sectional and panel data covering large sample of countries. These studies were justified by their ability to generalize empirical findings and their policy implications appeal. However, as suggested by Lin and Ye (2009) and Espinosa et al. (2010), due to the heterogeneous factors pertaining in different countries, it is important to carry out country specific studies in order to relate findings to policy designs with specific cases; inflation threshold effects should then be estimated for each country separately, allowing the incorporation of country specific characteristics; this would in particular provide useful information about the appropriate location and width of inflation targeting band. In line with these suggestions, this research is a contribution to the literature of developing country study cases on the existence of threshold effects in the relationship between inflation and economic growth.

To the best of our knowledge, no such research has been conducted so far using time series data for Rwanda. However, in two empirical studies1 based on a panel data set of industrial and developing countries, including Rwanda, Kremer et al. (2009) showed that for developing countries, inflation is detrimental to economic growth if it exceeds $17 \%$ and that below that threshold, the impact of inflation on growth was insignificant, while Pollin and Zhu (2005) estimated a threshold inflation range of $15-23 \%$ for low-income countries.

\section{Literature Review}

\subsection{Growth and Inflation}

Studies on the relationship that subsists between inflation and economic growth are vast in the empirical literature. Despite the varieties in the studies yet there is no convergence on the empirical findings as Samuelson \& Nordhaus (2015) stressed that while economists may disagree on the exact target for inflation, most agree that a predictable and stable or gently rising price level provides the best climate for healthy economic growth. However, Fischer and De Gregorio, (2010) found evidence for a negative link between inflation and growth. This was also confirmed by Barro and Andres \& Hernando (2017) who found a significant negative effect of inflation on economic growth. Gokal \& Hanif (2014) also examine the relationship between inflation and economic growth in Fiji for the period 1970-2013. The tests revealed that a weak negative correlation exists between inflation and growth, while the causality between the two variables ran one-way from GDP growth to inflation. Nevertheless, studies by Levine \& Zervos (2010), suggested that inflation was not a robust determinant of economic growth.

Furthermore, as Sarel (2009) provides a threshold point estimate of 9.9 per cent, Khan \& Senhadji (2011) identifies a 10.5 per cent inflation threshold as statistically significant to explain the inflation-growth nexus in Nigeria. Yet, Drukker, Gomis-Porquer as \& Hernandez- Verme (2015) suggest a two-threshold point model with 11.2 and 12.0 per cent as the appropriate inflation threshold points for Nigeria. Doguwa (2012), however, re-examines the issue of the existence and the level of inflation threshold in the relationship between inflation and growth, using three different approaches that provide appropriate procedures for estimating the threshold level and inference. The results suggest that the threshold level of inflation above which inflation is inimical to growth is estimated at 10.5 to 12 per cent for Nigeria.

As it appears in the above empirical literature review, most of the studies on the threshold effects of inflation on economic growth used cross-sectional or panel data covering a large number of countries. However, a few studies on emerging and developing countries applying the methodology developed by Khan and Senhadji $(2000,2001)$ used time series data to estimate the threshold level of inflation for individual countries ; they include among others , Sargsyan (2005) for Armenia, Mubarik (2005) for Pakistan, Seleteng ( 2005 ) for Lesotho, Ahmed and Mortaza (2005) for Bangladesh, Kheir El-Din and Abou-Ali (2008) for Egypt, Risso and Carrera for Mexico (2009),Salami and Kelikume (2010) for Nigeria , Quartey (2010) for Ghana and Singh for India (2010). These studies confirmed the existence of an inflation threshold effects on economic growth in the different country specific cases.

During the period covered by this research, the Rwandan economy experienced mixed performances; economic growth and inflation have been characterized by important fluctuations, resulting from combined effects of domestic and external factors. The domestic factors included in particular, the supply shocks due to recurrent climate conditions, to the breakdown of Rwanda's system of production and distribution during the period of war in 1990-1994 and the demand shocks reflecting the effects of monetary and fiscal policies. Regarding the external factors, the period under consideration has been marked by two oil price shocks in 1973-1974 and 1979-1980, and the combined increase in prices of oil and food products in 2003-2008.

As a first step in exploring the bi-variate relationship between growth and inflation, Figure 1 illustrates the historical trends of the two macroeconomic variables. The annual average of real economic growth rate for the whole sample period was $5.4 \%$, while average inflation rate was 9.5\% As can be seen through the graph in Figure 1 , the Rwandan economy witnessed two severe recessions and the highest inflation rates in 1974 and 1994, reflecting respectively the oil price shock in 1973-1974 and the collapse of the national economy at the end of the war period. As a consequence of these shocks indeed, the real GDP contracted by $11.3 \%$ in 1974 and $64.5 \%$ in 1994, while inflation was as 
high as $32.6 \%$ and $64 \%$ in the same periods. In both cases, the slowdown of the overall economic activity was followed by a strong and sustained recovery in subsequent years. However, the recovery was accompanied by higher inflation rates reflecting expansionary macroeconomic policies implemented by the government to stimulate economic growth.

\section{Methodology}

Vector Error Correction Model (VECM); This is a restricted VAR which help to estimate the speed the dependent variable; in this case GDP returns to equilibrium after there are changes in the explanatory variables. VECM can only be applied if the co-integration test proves existence of a rough long-run relationship between the variables, to estimate the shot-run dynamics as well as the transitory aspect or long-run dynamics of the variables. The dynamic relation established by the model with correction of error ECM is deducted from relation of long term rising from the method of Engel and Granger, the characteristics of the models with correction of the error is to combine in the same specification of the effects of that short term with those of the long term, thus all the information of long term on the level of variables is stored in the model (Atari et al., 2011). Around the long run relationship, the error correction model permits to integrate the short run fluctuations, if the coefficient comes negative it would change model in the long run equilibrium so with E-views the long run model would be done the short run model.

Granger causality test: Unlike other tests that simply identify the relationship between variables, Granger causality tests checks the causal relationship, this test is used to determine whether one time series will use to forecast another. (Granger, 2009), points out that causality is said to exist between two variables when a variable (X1) Grangercauses (predicts) another variable (X2) better than that variable can predict itself.'[T] he statement 'yicausesyj' is just shorthand for the more precise, But longwinded, statement, 'yi contains useful information for predicting yj(in the linear least squares sense), over and above the past histories of the other variables in the system' (Diebold, 2011)

\section{Results and Discussions}

The results of the relationship of macroeconomic variables and economic growth showed that it is clearly visible from the results that macroeconomic variables influence the process of economic development in Rwanda. Both variables of the study model (macroeconomic variables) affected the economic growth positively. These results provide some important implications for the regulators that they were concatenated on the macroeconomic variables.

$\mathrm{GDP}=0.022778+5.265210 \mathrm{Inf}+4.012108 \mathrm{Ert}+2.516107 \mathrm{Irt}$

The results showed that all macroeconomics variables have positive impact on gross domestic product, all coefficients of variables have positive sign, (5.265210) Inf, (4.012108) Ert and (2.516107) Irt. This showed that macroeconomics variables contribute positively on the economic growth in Rwanda from 2003-2018.

This showed that all variables were contributed positively on the economic growth. R2 $(0.055132)$ this show the goodness of fit the model.

The findings of the Error Collection Model, which incorporate the effect of macroeconomic variables and economic growth, estimated through ECM testing approach. As such, inflation rate (5.265210), exchange rate (4.012108) and interest rate (2.516107) are significant related to economic growth. It shows that macroeconomic variables stimulate the economic activities and development process in the country to a greater extent, which is obvious from the higher positive value of its coefficient.

Model Specification

The model looks like this: $\mathrm{Y}=\mathrm{f}(\mathrm{Inft}+\mathrm{Ert}+\mathrm{Irt})$, this model applied before by Levine:

$\mathrm{Y}=$ aggregate output (real GDP), Inft: Inflation at time $t$,

Ert: Exchange rate at time $t$, Irt: Interest rate at time $t$,

$\mathrm{GDP}=\beta 0+\beta 1$ Inft $+\beta 2 \mathrm{Ert}+\beta 3$ Irt $+\varepsilon$

LNGDP $=\beta 0+\beta 1 \mathrm{LNInf}+\beta 2 \mathrm{LNErt}+\beta 3 \mathrm{LNIrt}+\varepsilon \ldots$

DLNGDP $=\beta 0+\beta 1$ DLNInf $+\beta 2$ DLNErt $+\beta 3$ DLNIrt $+\varepsilon \ldots$ (3)

Where $\beta 0=$ is the intercept;

$\beta 1, \beta 2, \beta 3$, =are the parameters of the model of regression. $\varepsilon=$ Error term at period $\mathrm{t}$.

Expected signs

\begin{tabular}{|c|c|c|c|c|}
\hline Variables & GDP & Inf & Ert & Irt \\
\hline Expected signs & + & + & + & + \\
\hline
\end{tabular}

The model is:

$\mathrm{GDP}=\beta 0+\beta 1$ Inft $+\beta 2 \mathrm{Ertt}+\beta 3$ Irtt $+\varepsilon$ GDP is dependent variable.

Inf, Ert and Irt, have positive sign, it means that all dependents variables have positive contribution on gross domestic product.

\subsection{Test of Stationarity}

To test the stationarity, the unit root test was used or Dickey Fuller (DF) test, that would allow making the characteristic stationary or no chronologic series. There the simple Dickey Fuller test which suppose the error term to be white noise. The Augmented Dickey Fuller test (ADF) takes a reference from hypothesis. The DF and ADF tests using three models including one or many auto regressive differentials.

In order to make the good analysis, the researcher starts by analyzing the model: 


\section{$\mathrm{GDP}=\beta 0+\beta 1$ Inft $+\beta 2 \mathrm{Ertt}+\beta 3$ Irtt $+\varepsilon \mathrm{t}$}

This model is composed by some variables which the data was collected in billion, million and thousand. This model is the linear model and it is not easy to analyze it because all data are not picked in the same amount, that is why the researcher wants to introduce ( $\mathrm{Ln}$ ) in this model in order to avoid the spurious problem and it was became the log-log model.

Linear model: GDPt $=\beta 0+\beta 1 \mathrm{Inft}+\beta 2 \mathrm{Ertt}+\beta 3 \mathrm{Irtt}+\varepsilon \mathrm{t}$

Log-log model: LNGDPt $=\beta 0+\beta 1 \mathrm{LNInft}+\beta 2 \mathrm{LNErtt}+\beta 3 \mathrm{LNIrtt}+\varepsilon \mathrm{t}$

A stochastic process satisfying the above conditions is said to be weakly stationary. A time series that does not satisfy these conditions is said to be no- stationary. So, a non-stationary process was varying over time a changing or both.

A non- stationary process can be stationarized by differencing it nth times. A time series is said to be integrated of order d, written I (d), when after being differencing it ' $d$ ' times it becomes stationary. A series is integrated of order zero when it is stationary at level (Tharawanji, 2009).

Model Specification

The model looks like this: $\mathrm{Y}=\mathrm{f}$ (Inft+ Ert+Irt), this model applied before by Levine:

$\mathrm{Y}=$ aggregate output (real GDP), Inft: Inflation at time $t$,

Ert: Exchange rate at time $t$, Irt: Interest rate at time $t$,

$\mathrm{GDP}=\beta 0+\beta 1 \mathrm{Inft}+\beta 2 \mathrm{Ert}+\beta 3 \mathrm{Irt}+\varepsilon$

LNGDP $=\beta 0+\beta 1$ LNInf $+\beta 2$ LNErt $+\beta 3$ LNIrt $+\varepsilon \ldots$

DLNGDP $=\beta 0+\beta 1 D L N I n f+\beta 2$ DLNErt $+\beta 3$ DLNIrt $+\varepsilon \ldots$ (3)

Where $\beta 0=$ is the intercept;

$\beta 1, \beta 2, \beta 3$, =are the parameters of the model of regression. $\varepsilon=$ Error term at period $\mathrm{t}$.

Expected signs

\begin{tabular}{|c|c|c|c|c|}
\hline Variables & GDP & Inf & Ert & Irt \\
\hline Expected signs & + & + & + & + \\
\hline
\end{tabular}

Table 2: Sign

The model is:

$\mathrm{GDP}=\beta 0+\beta 1 \mathrm{Inft}+\beta 2 \mathrm{Ertt}+\beta 3$ Irtt $+\varepsilon$ GDP is dependent variable.

Inf, Ert and Irt, have positive sign, it means that all dependents variables have positive contribution on gross domestic product.

\subsection{Test of Stationarity}

To test the stationarity, the unit root test was used or Dickey Fuller (DF) test, that would allow making the characteristic stationary or no chronologic series. There the simple Dickey Fuller test which suppose the error term to be white noise. The Augmented Dickey Fuller test (ADF) takes a reference from hypothesis. The DF and ADF tests using three models including one or many autoregressive differentials.

In order to make the good analysis, the researcher starts by analyzing the model:

$\mathrm{GDP}=\beta 0+\beta 1 \mathrm{Inft}+\beta 2 \mathrm{Ertt}+\beta 3$ Irtt $+\varepsilon \mathrm{t}$

This model is composed by some variables which the data was collected in billion, million and thousand. This model is the linear model and it is not easy to analyze it because all data are not picked in the same amount, that is why the researcher wants to introduce ( $\mathrm{Ln}$ ) in this model in order to avoid the spurious problem and it was became the log-log mod Linear model: GDPt $=\beta 0+\beta 1$ Inft $+\beta 2$ Ertt $+\beta 3$ Irtt $+\varepsilon t$

Log-log model: LNGDPt $=\beta 0+\beta 1$ LNInft $+\beta 2$ LNErtt $+\beta 3$ LNIrtt $+\varepsilon t$

A stochastic process satisfying the above conditions is said to be weakly stationary. A time series that does not satisfy these conditions is said to be no- stationary. So, a non-stationary process was varying over time a changing or both.

A non- stationary process can be stationarized by differencing it nth times. A time series is said to be integrated of order d, written I (d), when after being differencing it 'd' times it becomes stationary. A series is integrated of order zero when it is stationary at level (Tharawanji, 2009).

\begin{tabular}{|c|c|c|c|c|c|c|c|}
\hline \multicolumn{7}{|c|}{ Unit Root Test at Second Different } \\
\hline & & & & R & & \\
\cline { 1 - 7 } Variables & & ADF & CV & Prob & squared & DW & LAG \\
\hline GDP & Intercept & -7.23721 & -3.05217 & 0 & 0.788906 & 2.322868 & 3 \\
\hline Infl & Intercept & -5.01472 & -2.96397 & 0.0003 & 0.473163 & 1.953331 & 5 \\
\hline \multicolumn{7}{|c|}{ Unit root test at level } \\
\hline Ert & Intercept & -4.65461 & -2.96041 & 0.0008 & 0.427617 & 2.133743 & 3 \\
\hline \multicolumn{7}{|c|}{ Unit Root Test at Level at Second Different } \\
\hline Irt & None & -22.3329 & -1.95441 & 0 & 0.992123 & 1.681913 & 5 \\
\hline \multicolumn{7}{|c|}{ Table 3: Analysis and Interpretation of the Data } \\
Unit Root Test
\end{tabular}


Referring to above table, research observes that GDP is stationary at level of intercept at lag 2 and Infl is stationary at intercept on lag 5 while Ert and Irt were stationary at intercept and None with lag $3 \& 5$.

Test of Residuals By using the ADT Unit Root test on the residuals estimated from the co- integrating regression, the econometric package E-views version 7 gives the following results.

\begin{tabular}{|c|c|c|c|c|}
\hline \multicolumn{5}{|c|}{ Null Hypothesis: $R$ has a unit root } \\
\hline Exogenous: None & & & & \\
\hline \multicolumn{5}{|c|}{ Lag Length: 0 (Automatic - based on SIC, maxlag=6) } \\
\hline & & & t-Statistic & Prob.* \\
\hline \multicolumn{3}{|c|}{ Augmented Dickey-Fuller test statistic } & -4.92772 & 0.0001 \\
\hline \multirow[t]{3}{*}{ Test critical values: } & $1 \%$ level & & -2.69977 & \\
\hline & $5 \%$ level & & -1.96141 & \\
\hline & $10 \%$ level & & -1.60661 & \\
\hline \multicolumn{5}{|c|}{ *MacKinnon (1996) one-sided p-values. } \\
\hline \multicolumn{5}{|c|}{ Augmented Dickey-Fuller Test Equation } \\
\hline \multicolumn{5}{|c|}{ Dependent Variable: $\mathrm{D}(\mathrm{R})$} \\
\hline \multicolumn{5}{|c|}{ Method: Least Squares } \\
\hline \multicolumn{5}{|c|}{ Date: $05 / 06 / 19$ Time: $15: 02$} \\
\hline \multicolumn{5}{|c|}{ Sample (adjusted): 2003Q1 2018Q4 } \\
\hline \multicolumn{5}{|c|}{ Included observations: 60 after adjustments } \\
\hline Variable & Coefficient & Std. Error & t-Statistic & Prob. \\
\hline $\mathrm{R}(-1)$ & -0.8837 & 0.472104 & -1.87184 & 0.0001 \\
\hline R-squared & 0.953128 & \multicolumn{2}{|c|}{ Mean dependent var } & 338.3694 \\
\hline Adjusted R-squared & 0.095128 & \multicolumn{2}{|c|}{ S.D. dependent var } & 2307.612 \\
\hline S.E. of regression & 2195.11 & \multicolumn{2}{|c|}{ Akaike info criterion } & 18.26091 \\
\hline Sum squared resid & $1.30 \mathrm{E}+08$ & \multicolumn{2}{|c|}{ Schwarz criterion } & 18.30849 \\
\hline Log likelihood & -254.653 & \multicolumn{2}{|c|}{ Hannan-Quinn criter. } & 18.27546 \\
\hline Durbin-Watson stat & 1.131954 & & & \\
\hline
\end{tabular}

Table 4: Residuals test

Referring to the above Table 3 the residual is stationary, t-statistic $(-4.927723)$ is less than critical value ($1.961409)$ and the probability (0.0001) is less than $5 \%$ and this table shows that the Durbin- Watson Stat is greater than R2 which is (1.131954) > 0.953128$)$. Basing on those results, the researcher found that R-squared is significant at 95\%. This means that three independents variables influence the economic growth of Rwanda. Research agrees that the result of (Hamid \& Sumit,2011), examined the relationship between macroeconomic variables and economic growth for 21 emerging markets over 21 years, using a dynamic panel method. Their results indicated a positive relationship between several indicators of macroeconomic and economic growth both in long run and short run by boosting private investment behavior.

\section{Estimation of Model}

To estimate the long run relation between variables Model: GDP $=\beta 0+\beta 1$ Inft $+\beta 2 \mathrm{Ertt}+\beta 3$ Irtt $+\varepsilon t$ After analyzing the stationarity by using the ADF Unit Root test, let's estimate this model by taking into the consideration the model of the variables that are stationary.

\begin{tabular}{|c|c|c|c|c|}
\hline \multicolumn{5}{|c|}{ Dependent Variable: GDP } \\
\hline \multicolumn{5}{|c|}{ Method: Least Squares } \\
\hline \multicolumn{5}{|c|}{ Date: 05/06/19 Time: 17:46 } \\
\hline \multicolumn{5}{|c|}{ Sample: 2003Q1 2018Q4 } \\
\hline \multicolumn{5}{|c|}{ Included Observations: 60} \\
\hline Variable & Coefficient & Std. Error & t-Statistic & Prob. \\
\hline Inf & 5.265210 & 1.712110 & 3.418454 & 0.0019 \\
\hline Ert & 4.012108 & 2.911208 & 1.274603 & 0.0066 \\
\hline Irt & 2.516107 & 2.082507 & 1.351976 & 0.0072 \\
\hline $\mathrm{C}$ & 0.022778 & 624.2051 & 0.455424 & 0.6523 \\
\hline R-squared & 0.055132 & \multicolumn{2}{|c|}{ Mean Dependent Var } & 1467.438 \\
\hline Adjusted R-Squared & 0.219610 & \multicolumn{2}{|c|}{ S.D. Dependent Var } & 2282.372 \\
\hline S.E. Of Regression & 2016.240 & \multicolumn{2}{|c|}{ Akaike Info Criterion } & 18.17232 \\
\hline Sum Squared Resid & 1.142408 & \multicolumn{2}{|c|}{ Schwarz Criterion } & 18.35554 \\
\hline Log Likelihood & -286.7572 & \multicolumn{2}{|c|}{ Hannan-Quinn Criter. } & 18.23306 \\
\hline F-Statistic & 3.907913 & \multicolumn{2}{|c|}{ Durbin-Watson Stat } & 1.691052 \\
\hline Prob(F-Statistic) & 0.018909 & & & \\
\hline
\end{tabular}

Table 5: Co-integration (Long Run Relationship)

Estimation Equation:

$\mathrm{GDP}=\mathrm{C}(1) * \operatorname{Inf}+\mathrm{C}(2) *$ Ert $+\mathrm{C}(3) *$ Irt Substituted Coefficients: 
GDP $=5.265210 *$ Inf $+4.012108 *$ Ert $+2.516107 *$ Irt

$\beta 0=0.022778$

$\mathrm{GDP}=0.022778+5.265210 \mathrm{Inf}+4.012108 \mathrm{Ert}+2.516107 \mathrm{Irt}$

Co-integration is an econometric property of time series variables. If two or more variables are themselves non-stationary, but a linear combination of them is stationary, the theory of time series are said; to be co integrated it is often said that co integration is a means for correctly testing hypothesis concerning the relationship between two variables having unit roots. Testing co integration, there are two most popular approaches, the Engle Granger (EG) two steps method and Johansen procedure. The first is analysis of stationarity for the residuals from the levels regression.

The variables were co- integrated; all variables have a long run relationship between them. Therefore, the researcher confirms that all variables are co-integrated and there is long run relationship between variables.

\section{Discussion and Interpretation}

The results of the relationship of macroeconomic variables and economic growth presented in Table 4. It is clearly visible from the results that macroeconomic variables influence the process of economic development in Rwanda. Both variables of the study model (macroeconomic variables) affected the economic growth positively. These results provide some important implications for the regulators that they were concatenated on the macroeconomic variables.

$\mathrm{GDP}=0.022778+5.265210 \mathrm{Inf}+4.012108 \mathrm{Ert}+2.516107 \mathrm{Irt}$

The results shows that all macroeconomics variables have positive impact on gross domestic product, all coefficients of variables have positive sign, (5.265210) Inf, (4.012108) Ert and (2.516107) Irt. This shows that macroeconomics variables contribute positively on the economic growth in Rwanda from 2003-2019.

This shows that all variables were contributed positively on the economic growth. R2 (0.055132) this show the goodness of fit the model.

\subsection{Error Correction Model (ECM)}

Error Correction Models (ECMs) is a category of multiple time series models that directly estimate the speed at which a dependent variable (Robin Best, 2011).

$\mathrm{Y}$ - Returns to equilibrium after a change in an independent variable - X.

ECMs are useful for estimating both short term and long-term effects of one time series on another. ECMs are useful models when dealing with integrated data but can also be used with stationary data. The dynamic relation established by the model with correction of error ECM is deducted from relation of long term rising from the method of Engel and Granger, the characteristics of the models with correction of the error is to combine in the same specification of the effects of that short term with those of the long term, thus all the information of long term on the level of variables is stored in the model (Judith, 2011). Around the long run relationship, the error correction model permits to integrate the short run fluctuations, if the coefficient comes negative it would change model in the long run equilibrium so with E-views the long run model was done the short run model.

\begin{tabular}{|c|c|c|c|c|}
\hline \multicolumn{5}{|c|}{ Dependent Variable: GDP } \\
\hline \multicolumn{5}{|c|}{ Method: Least Squares } \\
\hline \multicolumn{5}{|c|}{ Date: 05/06/19 Time: 18:04 } \\
\hline \multicolumn{5}{|c|}{ Sample (adjusted): 2003Q2 $2018 Q 4$} \\
\hline \multicolumn{5}{|c|}{ Included observations: 60 after adjustments } \\
\hline Variable & Coefficient & Std. Error & t-Statistic & Prob. \\
\hline $\mathrm{C}$ & 0.082806 & 614.2038 & 1.622068 & 0.1169 \\
\hline Inf & 3.432410 & $1.94 \mathrm{E}-10$ & 0.994922 & 0.0029 \\
\hline Ert & 0.212108 & 5.152408 & 1.790498 & 0.0050 \\
\hline Irt & 2.201208 & 2.061207 & 0.252162 & 0.0029 \\
\hline $\mathrm{R}(-1)$ & -0.085066 & 0.439025 & -0.330257 & 0.0026 \\
\hline R-Squared & 0.056016 & \multicolumn{2}{|c|}{ Mean Dependent Var } & 1488.290 \\
\hline Adjusted R-Squared & 0.430018 & \multicolumn{2}{|c|}{ S.D. Dependent Var } & 2316.999 \\
\hline S.E. Of Regression & 1749.268 & \multicolumn{2}{|c|}{ Akaike Info Criterion } & 17.91847 \\
\hline Sum Squared Resid & 79558393 & \multicolumn{2}{|c|}{ Schwarz Criterion } & 18.14976 \\
\hline Log Likelihood & -272.7363 & \multicolumn{2}{|c|}{ Hannan-Quinn Criter. } & 17.99387 \\
\hline F-Statistic & 6.658312 & \multicolumn{2}{|c|}{ Durbin-Watson Stat } & 2.064655 \\
\hline Prob(F-Statistic) & 0.000790 & & \\
\hline
\end{tabular}

This table shows that $\mathrm{R}(-1)=-1.085016$, this means that as far as time is concerned, the errors will be corrected at time $\mathrm{t}$. The value of R(-1), all macroeconomic variables influence the economic growth. R2 (0.056016) show the goodness of fit the model. This means that from 2003-2018, the economic growth of Rwanda was stable.

$\mathrm{GDP}=0.022778+5.265210 \mathrm{Inf}+4.012108 \mathrm{Ert}+2.516107 \mathrm{Irt}-1.085016(\mathrm{R}-1)$ 
In view of goings on in the macroeconomics variables over recent years it might be interesting to inquire whether the behavior of the market (as represented, say, by the Dow- Jones Industrial Average) can be modeled as a case of 'long-run equilibrium plus error correction'. What might be a plausible model for long-run equilibrium in this case? Well, corporate stocks ultimately derive their value from the fact that they are claims on the profits made by firms. Thus, it seems reasonable to suppose that stock prices should reflect the present discounted value of the future (expected) stream of corporate profit.

\section{Conclusions and Recommendations}

Macroeconomics variables have reinforced the researcher to study the effect of macroeconomic variables on the economic growth of Rwanda. The effect of macroeconomics variables is empirically tested on GDP as a dependent variable for the period of $2003 q 1$ to $2018 q 4$. As such, the results show that macroeconomics variables have positive impact on GDP. The co-integration test illustrates that macroeconomics variables were co-integrated and influenced the long run relationships with GDP. Therefore, researcher accepts $\mathrm{H} 1 \# 0$ and rejectsH0.

The Central Bank of Rwanda should work closely with the commercial banks of Rwanda to implement policies in order to continue stabilize Rwanda economy. The Central Bank of Rwanda should strengthen on its monetary policies to regulate the level of inflation rate which can stimulate the economy of Rwanda.

The National Bank of Rwanda has to support all financial sectors of the economy in order to grow the GDP of each of these sectors. Some of the most important sectors with large influence GDP include the Agriculture sector, tourism sector, financial sector, etc. Gross Domestic Product can also be improved by creating a conducive environment in the country for both private and foreign investors. Proper fiscal and monetary policies should be enforced to control the level of inflation, exchange rate and interest rate.

The main objective of this paper was to empirically examine the relationship between inflation and economic growth in Rwanda and investigate the existence of possible threshold effects. To this end, annual time series spanning the period 1968-2010 have been used to estimate a quadratic regression model. The result estimates of the quadratic regression model provided evidence supporting the hypothesis of a nonlinear relationship in the inflation-growth nexus in Rwanda and the existence of a threshold level of inflation above which inflation is detrimental to economic growth; the estimated threshold level is $14.97 \%$. Moreover, the Granger causality test was performed to investigate the linear causation between inflation and growth in the regression model; the results of the test estimates revealed a unidirectional causality running from inflation to growth and no feedback effect from growth to inflation was detected, implying that the simultaneity bias does not seriously affect the coefficient of inflation in the regression model (Fischer, 1993; Khan and Senhadji , 2001).

This paper is the first attempt to address the threshold effect in the inflation-growth nexus in Rwanda; it is therefore crucial as it provides a baseline study in search of the optimal inflation for growth in Rwanda. In addition, the findings of this research are consistent with the results of other recent similar empirical studies carried out on developing countries (Risso and Carrera, 2009; Singh, 2010) and in particular with results obtained in panel and country specific studies for African economies (Combey and Nubukpo, 2010; Frimpong and Oteng- Abayie, 2010; Quartey, 2010; Salami and Kelikume, 2010; Seleteng et al., 2011.

The analysis of this paper has important policy implications. First, the findings of this study revealed a significant difference between the inflation target used for policy purposes in Rwanda and the estimated inflation threshold. Since the monetary authorities have been targeting an inflation level of around 5\% in the implementation of economic stabilization and structural adjustment programs, one could infer in light of this research, that monetary and fiscal policies applied in these programs were tighter than necessary and that there was room for higher economic growth with higher inflation rate without pushing the economy in an inflationary spiral. It follows that, while the primary objective of monetary policy implemented by the National Bank of Rwanda is the achievement and maintenance of price stability, the monetary authorities should also be mindful of the trade-off between inflation, growth and employment in a developing country such as Rwanda in which the production capacity is not fully utilized and where supply shocks are predominant. Second, on the basis of empirical evidence, this study suggests that the upper limit of inflation target for policy purposes in Rwanda should be $14.97 \%$ rather than 5\%; this implies that an easier monetary policy should be pursued when inflation is lower than the threshold level, while a tighter stance should be adopted if inflation approaches that level.

Finally, although the objective of this study was to shed light on the relationship between inflation and growth in Rwanda, some important related issues have not been addressed, such as the channels through which inflation exerts a negative effect on economic growth and the impact of inflation variability on output growth.These are crucial issues that deserve substantial additional attention and would provide useful directions for future investigations.

\section{References}

i. Agalega\&Antwi. ( 2013). Impact of Investment Activities on Economic Growth ofPakistan,. Business and Management Review , 94.

ii. Anaripour. (2011). Government Spending in a Simple Model of Endogenous Growth. Journal of Political Economy , 103-125.

iii. Balassa-Samuelson Hypothesis in Asia. In Ito, T. and A.O. Krueger (Eds) . (2016). Changes in Exchange Rates in Rapidly Development Countries: Theory, Practice, and Policy Issues . Science direct, 109 -132.

iv. Barro and Andres \& Hernando . (2017). Determinants of Economic Growth: Panel Data Approach. Reserve Bank of Fiji Working , Barro and Andres \& Hernando (2017), Determinants of Economic Growth: Panel Data Approach, Reserve Bank of Fiji Working Paper No. 01/04. 
v. BNR. ( 2014). Likelihood Ratio Statistics for Autoregressive Time Series with a Unit Root. Econometrica, 10571072.

vi. Borio et al. (2015). Sources of Growth Revisited:The importance of the nature of technological progress. Journal of Applied Economics, 31-62.

vii. D'Adda \& Scorcu. (2014). D'Adda \& Scorcu (2014), Analysis of the Impact Factors of the Real Estate Market: Case Slovenia. Engineering Economics, 23 (4): 257-367. INZINERINE EKONOMIKA-ENGINEERING ECONOMICS', 257367.

viii. Dhonte \& Kapur. (2011). Treatise on Money and the General Theory of Employment, Interest and Money 1927 to 1939. New York,USA: University of Adelaide.

ix. Doguwa. (2012). Inflation Dynamics on the Overall Stock Market Performance: The Case of Nairobi Securities Exchange in Kenya. Economics and Finance Review, 78-81.

x. Donald J. Harris. (2009). Determinats of Residential Real Estate Prices in Nairobi. The East African Law Journal.

xi. Drukker, Gomis-Porqueras \& Hernandez-Verme . (2015). Factors Influencing Real Estate Property Prices. A Survey of Real Estates in Meru Municipality, Kenya. Journal of Economics and Sustainable Development.

xii. Ecker and Ivashina. ( 2015). Factors Affecting Economic Growth in Africa: Are there any lessons from China? . African Development Review, 468-493.

xiii. Edwards. (2015). Economic Growth Factor in Nigeria: The Role of Global Trade. American Journal of Humanities and Social Sciences, 51-55.

xiv. Feldstein. (2010). Co-integration and error-correction: Representation, estimation and testing. Quarterly Journal of Business Studies, 135-140.

xv. Fischer and De Gregorio. (1980 - 2009). Impact of Public Debt on an Emerging Economy: Evidence from Nigeria (1980 - 2009). International Journal of Innovative Research and Development, 8.

xvi. Grennes, Ghura. (2011). A Test of The Determinants of Economic Growth in Nigeria. Nigeria.

xvii. group, A. D. (2010). Impact of Macroeconomic Factors on Economic Growth in Ghana: A Cointegration Analysis. International Journal of Academic Research in Accounting, Finance and Management Sciences, , 35-45.

xviii. Imimole, Imoughele. (2012). The Impact of Different Macroeconomic Variables on Poverty in Pakistan. . Interdisciplinary Journal of Contemporary Research in Business, , 788-790. 